\title{
Trichomonas vaginalis: pathogenesis and its role in cervical cancer
}

\author{
José Núñez-Troconis \\ Department of Obstetrics and Gynecology, Faculty of Medicine, Universidad del Zulia, \\ Maracaibo, Venezuela.
}

Key words: Trichomonas vaginalis; cancer of the cervix; inflammation mechanisms; carcinogenesis; sexual transmitted infection; Trichomonas vaginalis virus.

\begin{abstract}
The objective of this article was to review and to analyze the possible role that Trichomonas vaginalis has as a co-factor in the origin and development of cervical cancer. For that purpose, the Latin-American and international bibliography was reviewed using the Pub-Med, Google Scholar, Springer, the Cochrane Library, Embase, Scielo, Imbiomed-L, Redalye and Latindex web sites. The searches included the key words: Trichomonas vaginalis, epidemiology of Trichomonas vaginalis, epidemiology of cervical cancer, inflammation mechanisms, Trichomonas vaginalis and inflammation mechanisms, Trichomonas viruses, carcinogenesis, cervical cancer and co-factors, sexually transmitted infections and cervical cancer, cancer and inflammation mechanisms, Trichomonas vaginalis and cervical cancer. Publications from 1970 to June 2020 were reviewed and analyzed. This review article analyzes the possible mechanisms that Trichomonas vaginalis could play in the carcinogenesis of the cervical cancer as a co-factor with the human papilloma virus or as an independent factor.
\end{abstract}

Corresponding author: José Núñez-Troconis. Department of Obstetrics and Gynecology, Faculty of Medicine,Universidad del Zulia, Maracaibo, Venezuela. E-mail: jtnunezt@gmail.com 


\title{
Tricomonas vaginalis: patogénesis y su papel en el cáncer cervical.
}

\author{
Invest Clin 2020; 61 (4): 349-375
}

Palabras clave: Tricomonas vaginalis; cáncer del cuello uterino; mecanismo de la inflamación; carcinogénesis; infecciones de transmisión sexual; virus de la Trichomonas vaginalis.

Resumen. El objetivo del artículo fue revisar y analizar el posible papel que el protozoario flagelado Tricomonas vaginalis tiene como co-factor en el origen y desarrollo del cáncer del cuello uterino. Para dicho propósito, se revisó la bibliografía latino-americana e internacional en las páginas electrónicas de Pub-Med, Google Scholar, Springer, la biblioteca Cochrane, Embase, Scielo, Imbiomed-L, Redalyc and Latindex. La búsqueda incluyó las palabras claves: Tricomonas vaginalis, epidemiología de Trichomonas vaginalis, epidemiología del cáncer cervical, mecanismos de la inflamación, Trichomonas vaǵinalis y mecanismos de la inflamación, virus de Tricomonas vaginal, carcinogenesis, cáncer cervical y co-factores, infecciones de transmisión sexual y cáncer cervical, mecanismos de la inflamación y cáncer cervical. Se revisaron y analizaron las publicaciones desde 1970 hasta junio 2020. Este artículo de revisión analizó los posibles mecanismos que la Tricomonas vaginalis pudiera jugar en la carcinogénesis del cáncer del cuello uterino tanto como co-factor con el virus del papiloma o como un factor independiente.

Received: 04-08-2020 Accepted: 24-10-2020

\section{INTRODUCTION}

Vaginal discharge is the most common cause of gynecological consultation (1). The most common vaginal discharges are bacterial vaginosis (BV) produced by Gardnerella vaginalis (Gv), Candida albicans (CA) and Trichomonas vaǵinalis (Tv) $(2,3)$. Table I shows the most common causes of vaginal discharge (4). Tv is the most common, prevalent, curable non-viral sexually transmitted infection (STI) worldwide $(5,6)$.

\section{METHODOLOGY}

Literature searches were performed electronically in PubMed, Medline, ISI,
Springer, Embase, Web of Knowledge, DOAJ, Google Scholar and the Cochrane Library for original articles written in the English language and in Scielo, Latindex, ImbiomedL, Redalye and Google Scholar for original articles written in the Spanish language. Selection criteria included randomized clinical trials, observational trials, open-label nonrandomized trials, and case reports related to $T v$ and cervical cancer. The Cochrane Library was searched for reviews. Publications from 1970 to June 2020 were reviewed. Three hundred and ninety references were found and 150 met the inclusion criteria.

The searches included the key words (Mesh): Trichomonas vaginalis, epidemiology of Trichomonas vaǵinalis, epidemiology 
TABLE I

CAUSE OF VAGINAL DISGHARGE.

\begin{tabular}{|c|c|c|}
\hline Non-Infective & Non-STI & STI \\
\hline Physiological & $\begin{array}{l}\text { Bacterial } \\
\text { Vaǵinosis }\end{array}$ & $\begin{array}{l}\text { Chlamydia } \\
\text { trachomatis }\end{array}$ \\
\hline Cervical Ectopy & $\begin{array}{l}\text { Candida } \\
\text { Albicans }\end{array}$ & $\begin{array}{l}\text { Neisseria } \\
\text { gonorrhea }\end{array}$ \\
\hline Foreign Bodies & & $\begin{array}{c}\text { Trichomonas } \\
\text { vaginalis }\end{array}$ \\
\hline Vulvar Dermatitis & & \\
\hline
\end{tabular}

STI: Sexual Transmitted Infection.

of cervical cancer, Trichomonas vaginalis and infection, inflammation mechanisms, Trichomonas vaginalis and inflammation mechanisms, Trichomonas viruses, carcinogenesis, cervical cancer and co-factors, sexual transmitted infections and cervical cancer, cancer and inflammation mechanisms, Trichomonas vaginalis and cervical cancer. The electronic search and eligibility of the studies were evaluated by the author. The author reviewed, analyzed and discussed the Trichomonas and its role in cervical cancer.

\section{Epidemiology}

According to World Health Organization (WHO) (2), there are more than one million curable STIs that occur each day. Globally, it is estimated that for 2016, there were roughly 376 million new infections of the four curable STIs: Clamydia tracomatis (Ct), gonorrhea, syphilis and trichomoniasis as seen on Table II $(2,6)$. According to different authors $(2,6)$ the prevalence of $T v$ for 2016 was estimated in 5.3\% (95\% IC: 4.0 7.2 ) in women and $0.6 \%$ (95\% IC: $0.4-0.9$ ) in men, with regional values ranging from 1.6 to $11.7 \%$ in women and from 0.2 to $1.3 \%$ in men. Rowley et al (6) reported a Trichomoniasis incidence of 40 per 1000 in women (95\% IC: 27-58) and 42 per 1000 men (95\% IC: 23-69). Although $T$ is a worldwide parasite, prevalence and incidence rates differ or depend on the part of the world, the culture, the religion and the population studied
TABLE II

GLOBAL ESTIMATES OF NEW CASES OF CURABLE STIS IN 2016.

\begin{tabular}{lc}
\hline Sexual Transmitted Infection & No. (millions) \\
\hline Chlamydia trachomatis & 127 \\
Gonorrhea & 87 \\
Syphilis & 6 \\
Trichomonas vaginalis & 156 \\
Total & 376 \\
\hline
\end{tabular}

STIs: Sexual Transmitted Infections.

$(5,7) . T v$ is considered as the second most frequent STIs and the second most common cause of lower genital tract infection worldwide (8). WHO (2) reported that the African Region had the highest incidence rates for trichomoniasis in women and men. In the America region, the Pan-American Health Organization (9) reported an incidence of 18.8 million new cases of trichomoniasis among females, and 13.6 million new cases among men and a prevalence of 18.8 million existing cases of trichomoniasis among females, and 3.2 million existing cases among men in 2012. According to the Center for Disease Control and Prevention (10), the prevalence in USA of trichomoniasis is $2.1 \%$ in women between 15-49 years old and they estimate that 3.7 million people have trichomoniasis. Studies in Latin America revealed prevalence values of 7.6\% in Argentina (11), 7.8\% in Chile (12) and 9.1\% in Peru (13). In Brazil, prevalence ranged from $2.6 \%$ to $20 \%$ among women (14-16). In Venezuela, Núñez et al (17) reported a prevalence of $7 \%$. The incidence of $T$ infection depends on several risk factors including age, sexual activity, number of sexual partners, sexual partner promiscuity, menstrual phase, prostitution, imprisionment, use of illicit drugs, race, diagnostic techniques, low social and economic conditions, as well as other STIs such as Herpes Virus 1 and 2(HVS), Ct, CA, Gv, Gonorrhea (G), Human Papilloma Virus (HPV), Human Immunodeficiency Virus 
(HIV) $(10,18)$. The prevalence is high among low social income patients from gynecologic and STI clinics (18). Patel et al. (19) using urine samples found that $T v$ infection prevalence was $0.5 \%$ and $1.8 \%$ among males and females, respectively. To infection prevalence was $4.2 \%$ among black males, $8.9 \%$ among black females, and $0.03 \%$ and $0.8 \%$, respectively, among males and females of other races/ethnicities. To infection prevalence was positively associated with female sex (OR: 6.1; confidence interval 95\%(IC):3.311.3); black race (vs other races/ethnicities OR:7.9 IC 95\%:3.9-16.1); older age (vs 1824 years, OR: 3.0 IC 95\%:1.2-7.1) for 25- to 39-year-olds and OR: 3.5, IC 95\%: 1.3-9.4) for 40 to 59-year-olds); having less than a high school education (vs completing high school or more, OR: 2.0, IC 95\%:1.0-4.1); being below the poverty level (vs at or above the poverty level, OR: 4.0, IC 95\%:2.1-7.7); and having $\geq 2$ sexual partners in the past year (vs 0-1 sexual partners, OR:3.6, IC 95\%: 2.0-6.6).

To infection occurs in the female and male urogenital tract and humans are the only natural host for the parasite $(18,20)$. As all STIs, To is transmitted by sexual intercourse and the evidences that corroborate for the classification of trichomoniasis as STI are: 1.- high frequency of infection in urethra and/or prostate of male partners of infected women; 2 .- the prevalence of infection is higher among female attending in STD clinics and among prostitutes than in postmenopausal women and virgins; and 3.- To die outside of the human body, unless they are protected from desiccation $(18,21)$. To infection results in a variety of clinical manifestations in most cases the patients are asymptomatic, but some may develop signs typically associated to the disease. Moreover, beyond the symptoms, the main issue concerning trichomoniasis is its relationship with serious health consequences such as cancer $(22,23)$, adverse pregnancy outcomes $(24,25)$, infertility $(26,27)$, and HIV transmission and acquisition (28). The infection was traditionally known as symptomatic in women and asymptomatic in men (18), however, this currently is changing and recent data have mentioned that around $80 \%$ of $T v$ infections are asymptomatic in both men and women (29). Symptomatic women ranged between $50-85 \%(21,30-32)$ while in men the percentage was $15-77 \%(30,31)$.

\section{Pathobiology/Pathophysiology}

To was discovered in 1896 by the French medical doctor and microbiologist, Alfred F. Donné; in 1916, Hoehne showed the To was responsable for producing vaginitis (33). Tv belongs to the Trichomonadidae family. Four different types of Trichomonas (T) can be found in humans: T. hominis, T. tenax, T. vaginalis y Pentatricomonas hominis (Ptv). The $T$. hominis is found in the intestines, the $T$. tenax in the mouth, the Ptv in the intestines and $T v$ in the vagina and uretra. As it was mentioned, they parasite the urogenital area of women and men (5). Tv is a flagellated parasitic protozoan, typically pyriform but occasionally amoeboid in shape, extracellular to genitourinary track epithelium with a primarily anaerobic lifestyle (34). The individual organism is $8-20 \mu \mathrm{m}$ long and $2-14 \mu \mathrm{m}$ wide. Four flagella project from the anterior portion of the cell and one flagellum extends backwards to the middle of the organism, forming an undulating membrane. To has a foamy, cyanophilous cytoplasm (greenish grey on a Pap smear) with red granules, and eccentric, possibly red-coloured nucleus. An axostyle extends from the posterior aspect of the organism. Parallel to this membrane, a bundle of microtubules called the costa, is arranged inside the cell. It has a Golgi apparatus associated with microfilaments (the parabasal filaments) that, together, form the so-called parabasal body. Traversing the cytoplasm as an axis and protruding from the posterior end, it presents a structure also made up of microtubules called the axostil. This axostil, in its anterior part, widens and partially covers the nucleus. As a continuation of the axostil towards the anterior part, 
there is another microtubule structure, the pelta, which partially covers the basal structures of the flagella. The nucleus, which has an endosome, is arranged in the anterior zone, near the point of insertion of the flagella. In stains, the parabasal nucleusbody-axostil (anterior part) flat assembly is usually stained as a single mass. It lacks mitochondria and instead has organelles called paracostal bodies (because it is close to the costa) and paraxostillary bodies (because it is close to the axostil), which are hydrogenosomes, whose function is to produce energy (ATP) under anaerobic conditions (5). This hydrogenosome, is a mitochondrion-like organelle that generates hydrogen (35). Due to its microaerophilic lifestyle, Tv does not have the ability to generate ATP by oxidative phosphorylation but depends on substrate level phosphorylation. Originally, it was assumed that the hydrogenosome is an ancestral form of the mitochondrion. It is now apparent, based on phylogenetic studies, that the hydrogenosome constitutes a reduced form of fully developed mitochondria. Nevertheless, the hydrogenosome remains an intriguing organelle, and the extraordinary size of the To genome, exceeding $160 \mathrm{Mb}$, will certainly provoke further research in the years to come $(36,37)$. Tv has a large genome (strain G3, 176,441,227 bp) with $\sim 60,000$ protein coding genes organized into six chromosomes (38). Tv is a highly predatory obligate parasite that phagocytoses bacteria, vaginal epithelial cells and erythrocytes, and is itself ingested by macrophages. To uses carbohydrates as its main energy source via fermentative metabolism under aerobic and anaerobic conditions $(31,32)$.

Its incubation time is generally between 4 and 28 days (21). To primarily infects the squamous epithelium of the female and male urogenital tract. To resides in the female lower urogenital tract (vagina, urethra) and the male urethra and prostate, where it replicates by binary fission. Tv is transmitted among humans, its only known host, primarily by sexual intercourse. Infection may persist for long periods, possibly months or even years, in women but generally persists less than 10 days in males (39). The parasite does not appear to have a cyst form and does not survive well in the external environment, but can survive outside the human body in a wet environment for more than three hours $(5,31)$. However, there may be a pseudocyst form. To pseudocyst has been found to be more virulent in animals and could have relevance for humans, particularly in the case of cervical neoplasia $(40,41)$. To can be infected with double-stranded RNA (dsRNA) viruses that may have important implication for trichomonal virulence and disease pathogenesis (41-43). As it was mentioned before, $T v$ is transmitted during sexual intercourse; men also become infected (asymptomatic hosts), but most commonly exhibit urethral infections. Tv has to deal with constant stress in its physiological niche of the urogenital tract that includes changes in $\mathrm{pH}$, fluctuation in iron balance and other nutrients and desquamation of vaginal epithelial cells associated with menstrual cycle (44). In addition, the parasite may reside in the urethra of women from where it reinfects the cervico-vaginal segment upon the $\mathrm{pH}$ increase. When the lactobacilli have reinstated, the vaginal $\mathrm{pH}$ level returns to normal and the parasite disappears from the area since it cannot survive in an acid environment. Hence, the conclusion of some specialists according to which, some women heal by themselves. In fact, the parasite present in the urethra reinvades the vagina in the period prior to menses, when the $\mathrm{pH}$ increases to 7.5 and after the menstrual cycle, when the $\mathrm{pH}$ decreases again to 4.0-4.5, To moves back into the urethra. Thus, in the absence of a sustained therapy, reinfection occurs. The parasite adheres to the wall of the cervicovaginal cells and, by a very effective enzyme system, it interferes in the metabolism of the host generating toxins that may lead to cell necrosis. In addition, for survival, the parasite needs very little energy, which it acquires by the glycolysis of cellular 
glycogen $(5,45)$. It is known that parasitic protozoans have a variety of complex carbohydrates on their surfaces, e.g., glycolipids, glycoproteins, and lipid-anchored glycosylated phosphatidylinositol (GPI). These glycoconjugates have been reported to play important roles in host cell invasion and evasion of host immune responses by several protozoa $(46,47)$. Fichorova et al. (48) have demonstrated that Tv express lipophosphogilycans (LPGs) (2 106 to 3106 copies/ parasite) anchored on the cell surface via an inositolphosphoceramide $(49,50)$.

The high density of lipophosphogilycans (LPGs) on the parasite surface suggests that they have important roles in parasite biology and in the infections they cause. The same authors $(49,50)$ previously showed that pretreatment of trichomonads with periodate abolished adhesion of specific parasites to their respective host cells, implying the involvement of carbohydrate molecules in these processes (51). This is of a fundamental importance to understand the pathobiology of trichomoniasis and to define the role that this molecular component(s) play(s) in the infection of host tissues, in particular vaginal epithelial cells (VECs). Fichorova et al. (48) confirmed the role of surface carbohydrates in the adhesion of $T v$ to host epithelial cells in the lower female genital tract and strengthen the evidence of LPG involvement in this process.

\section{Adhesion}

In order to survive as an extracellular parasite, To must adhere to the epithelial lining or extracellular matrix components of the urogenital tract especially to VECs $(52,53)$. Attachment to cells, microorganisms or other surfaces, drives a transition of the ovoid free-swimming parasite into an amoeboid form which it is highly adherent (53) (Fig. 1). In addition to VECs, To can bind diverse cellular and non-cellular structures upon which a similar transition to an amoeboid form is observed. This suggests that the parasite utilizes either an adaptable non-specific or multiple specific bind- ing mechanisms to mediate attachment and signal its morphological remodelling (52).

Multiple molecules have been postulated to be involved in attachment of T. vaginalis to target cells (Fig. 1). These adhesion molecules can be separated into three categories: 1. a controversial set of metabolic proteins that appear to have secondary adhesive properties; 2. a lipophosphoglycan; and 3. a collection of membrane proteins, many of which have been recently identified through genomics and proteomics (52).

\section{Metabolic proteins}

The class of proteins designated as adhesion proteins (APs) consisting of AP23, AP33, AP51, AP65 and AP120 are the most controversial of the adhesion molecules (54). However, it has also been reported that these proteins are present on the surface of the parasite $(55,56)$. Finding proteins with multiple functions and localizations is reasonable; Alderete et al. (57) have reviewed about this dual function of these enzymes as metabolic proteins and adhesins. Other research groups, however, have provided immunofluorescent microscopic evidence that these molecules are located exclusively in the hydrogenosome, denying the dual localization (54). It has been shown that AP23, AP33, AP51 and AP65 adhere to several cell types and bind to these targets in the absence of membrane proteins $(54,58)$. These results suggest a nonspecific membrane binding, a property that would argue against a precise role in pathogenesis. Recent research shows that AP51 and AP65 bind to hem and hemoglobin, a property that paradoxically supports their promiscuous nature and lack of adherence specificity and implies a role in binding to a key nutrient (59).

It has recently been proposed that glyceraldehyde-3-phosphate dehydrogenase (GAPDH), a ǵlycolytic enzyme, is involved in adherence of $T v$ to the host extracellular matrix protein fibronectin and is considered with dual-functional: adhesins/enzymes (60). 


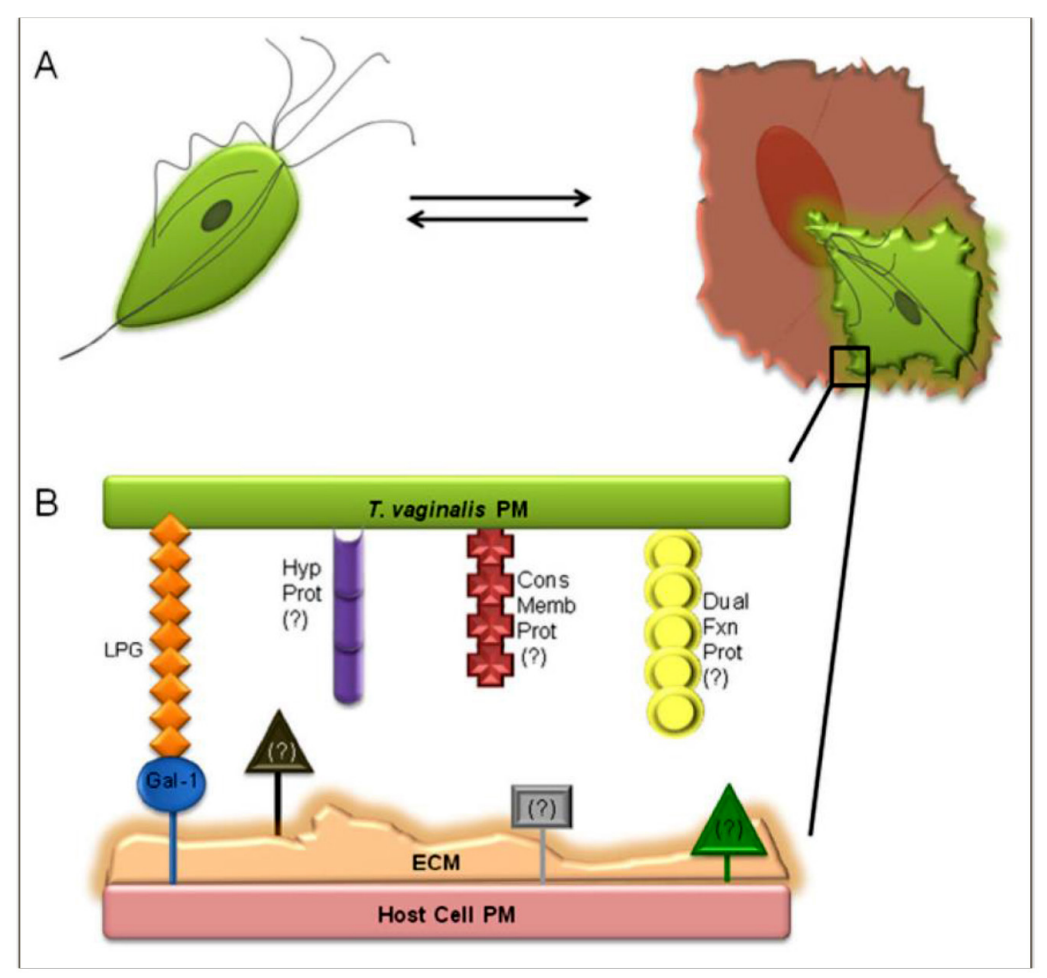

Fig. 1. T. vaginalis interaction with extracellular membrane (ECM) and host cell plasma membrane (PM). The ovoid free-swimming form of Trichomonas (upper left-hand side) transitions to an amoeboid form upon binding to a host epithelial cell (upper right-hand side). Lower panel: various T. vaginalis membrane molecules: LPG, hypothetical proteins (Hyp Prot), membrane proteins with conserved domains (Cons Memb Prot) and dual-functional proteins (Dual Fxn Prot) implicated in the interaction with ECM and host cell PM receptors. Galectin-1 (Gal-1) is the only reported host cell receptor. Adapted from: https://www.google.com/search?q=Trichomonas+vaginalis:+current + understandin $\mathrm{g}+\mathrm{of}+$ host $\% \mathrm{E} 2 \% 80 \% 93$ parasite + interactions\&sxsrf $=$ ALeKk01yqd1vojQZy74KRaq3mf_VB1SNVA:1 $596481107780 \&$ source $=\operatorname{lnms} \&$ tbm $=$ isch $\& s a=X \& v e d=2$ ahUKEwjpgsfK2_qAhUB66QKHUfaDoIQ_ AUoAXoECA4QAw\&biw $=1440 \& b i h=701 \#$ imgre $=u$ ovsGUaBog $\mathrm{CyOM}$.

\section{Lipophosphoglyean}

$T v$ is coated by a complex structure of glycoconjugates known as a glycocalyx. Studies of this glycocalyx began almost 40 years ago with looking lectin at the parasite surface (61). This investigation has been narrowed to a single surface glycan: LPG. Studies have suggested that surface carbohydrates, specifically terminal $\mathrm{N}$-acetylgalactosamine or galactose, are important in determining the virulence of To. It was found that treating parasites with glycosylases caused a more than 20 -fold reduction in binding of parasites to human VECs (62). In addition, exposure of $T v$ to periodate to oxidize the glycocalyx reduced parasite bind- ing to laminin and adhesion to human VECs (51). The first, and only, surface ǵlyconjugate isolated from $T v$ is the most abundant. With $2-3 \times 10^{6}$ molecules per cell, To LPG was thought to be a probable candidate to play a role in host-parasite interactions (49). This complex molecule is composed of an inositolphosphoceramide anchor (50) and a polysaccharide core composed of glucose, galactose, $\mathrm{N}$-acetylǵlucosamine, N-acetylgalactosamine, rhamnose and xylose at a composition of $4.2 \%$, $14.6 \%, 35.8 \%, 2.4 \%, 27.1 \%, 15.9 \%$, respectively. Several important biological functions have been attributed to To LPG. Several lines of evidence demonstrate that To LPG is an adhesion 
molecule: 1 . when LPG is added, the To biding to the epithelial cells are inhibited to epithelial cells $(48,49,63)$; 2 . LPG binds to human galectin-1 and this interaction results in host cell attachment (64). Although it is unclear whether galectin-1 binding causes alteration in host cell gene expression, LPG exposure to several epithelial cell types up-regulates interleukin- 8 and macrophage inflammatory protein $3 \alpha$ expression (48). Furthermore, LPG activates the pro-inflammatory transeription factor nuclear factor $\mathrm{KB}$ (65). These activities support a role for LPG in parasite attachment, specificity of binding and manipulation of host cell-gene expression. Even though several functions of To LPG have been defined, important questions remain unanswered. It is unclear if galectin-1 is the only receptor for LPG, as several other galectins could function as receptors, particularly galectin-3, which is expressed by VGEs (48).

\section{Membrane proteins}

When attempting to identify proteins involved in the attachment of a parasite to a host cell, an obvious starting place is proteins anchored to the parasite's surface. Several observations suggest that Trichomonas surface proteins are involved in attachment to host cells and structures. Trypsinization of the surface of $T v$ decreases binding of the parasite to laminin, fibronectin and several human cell lines (66). It has been found a membrane-localized protein is involved in the attachment of To (67). The completion of the $T v$ genome (38) has launched investigations of protein families that contain transmembrane domains and domains shared with surface proteins implicated in pathogenesis in other organisms (54). Four families encompassing 128 genes, encoding serine, cysteine and metalloproteases were identified. These proteases may play a role in degrading host proteins or extracellular matrix to clear attachment sites (54). Alternatively, they may be involved in degrading parasite-host bonds allowing the parasite to be released and transmitted to the next host. Additionally, three gene fami- lies encoding 47 proteins similar to surface proteins expressed in other mucosal pathogens, chlamydial polymorphic membrane proteins, immunodominant variable surface antigens and giardial VSP (variant surface protein)-like proteins, were identified (54). These bioinformatic analyses also revealed the presence of genes encoding 11 surface lectins that may bind to carbohydrates in the extracellular matrix or on the host cell (54). This possibility is strengthened by a previous observation that treatment of host cells with periodate to oxidize carbohydrates reduced parasite binding (68). Finally, the largest family identified through these studies was the BspA-like group named for their similarity to leucine-rich proteins of mucosal bacteria known to mediate adherence to host cells (54). This gene family was initially found to encode 658 proteins, but further analysis revealed 911 proteins with 191 containing predicted transmembrane. Furthermore, indirect immunofluorescence shows that at least one family member, TvBspA-625 (where TvBspA is To BspA), is expressed on the surface of the parasite $(54,69)$. Future experiments are needed to determine the expression patterns of predicted membrane proteins and to provide direct evidence for their involvement in the interaction of $T v$ with its host. Understanding both the function and expression patterns of these proteins will be critical to determine whether any, may be valid targets for rational drug or vaccine desiǵn.

\section{Virulence}

The importance of maintaining an intact mucosal layer is crucial to avoid the occurrence of pathological disorders associated with inflammatory disease, in which disruption of the epithelial barrier leads to severe inflammation of the mucosal tissue compartments (70-73). The epithelial barrier is maintained by connections between adjoining epithelial cells, which are the first sites of contact with the host. These cells are responsible for separating potentially harm- 
ful luminal content from the underlying tissue. This function of acting as a physical barrier is accomplished by junctional complex, which comprises a plethora of membrane-associated and transmembraneous proteins organized in discreet, spatially restricted complexes $(72,73)$. For establishing infection, Lin et al. (70) findings provide solid evidence to support claims that the damages of $T v$ infection to host cells and cell junctions is initiated by the attachment of live parasites. To requires to break through the mucus layer and adhere to epithelial cells of urogenital tract (74). It also penetrates into basement membrane and binds to extracellular matrix proteins (75). Previous reports have shown that host cells infected by Tv presented disruption before being lysed $(76,77)$.

Epithelial cells act in a manner similar to that of a connector in a host-microbe communications network, building signal transduction connections between luminal microbes and the host $(76,77)$. To virulence depends on two factors: cytoadherence and cytotoxicity (78). Studies using the scanning electronic microscope and transmission electronic microscope on samples collected from patients with $T v$ vaginitis showed that the capacity to adhere to VECs lead To to development of pseudopodial and filopodial processes giving a distinct form which is spherical or ovoid (79-82). Furthermore, there is a reason to suspect that the adhesiveness and amoeboid form of $T v$ contribute in an important way to the pathogenesis and virulence. Health (81) found that the damage to VEGs is related to the adhesion of this amoeboid form to the cells. The adhesiveness is a mechanism for increasing the efficiency of parasite-derived cytotoxic and cytolytic factors since they could act at short range between the VEC and the adhering amoeboid To (81). Also, several products from the parasite's metabolism such as lactic acid, hydrolytic enzymes: hyalurodinase, glicosidases, mucinases, adhesins, and acid phosphatase contribute to the cytotoxitciy (74). The amoeboid movements of Tv, act- ing alone or together with the sectored factors, and provide a mechanism for injuring the epithelial cells. Heath (81) showed that this amoeboid movements of To are important in disrupting the epithelial cells. The author (81) concluded that both mechanisms, mechanical and chemical, work in the human $T v$ infection. The adhesion of $T v$ to the vaginal and exocervical epithelia could be an important role in disrupting the superficial layers of squamous epithelium causing the necrosis and increasing the rate of desquamation which are very common features of severe To vaginitis. Also, some authors have mentioned that there is an increased in the sub-epithelial vascularity of the vagina and cervical walls, in other words an acute inflammation $(80,82)$. Trichomonas requires to break through the mucus layer and adhere to epithelial cells of the urogenital tract (74). It also penetrates into the basement membrane and binds to extracellular matrix proteins (75). Although pathogenesis and virulence in human trichomoniasis is not fully understood, progress has been made in identifying parasite products that can damage host cells and tissues.

\section{Molecular mechanisms}

Adhesion is thought to play an important role in the pathogenesis of trichomoniasis, and investigations of the molecular basis of adhesion of $T v$ to human cells have identified several adhesion molecules (Ad) on the surface of the parasite. Much of the evidence for the role of $\mathrm{Ad}$ in pathogenesis has come from co-culture experiments in which antibodies to Ad were shown to reduce parasite adhesion and subsequent cytopathic effects [CE] on host cells (83). Additional studies had shown that contact of To with mammalian targets eaused up-regulation of $\mathrm{Ad}$ and that the parasite assumed a flattened shape, essentially laminating itself to the host cell (75). Cysteine proteinases seem to be neeessary for efficient Ad-mediated adhesion of parasites to targets (84). Control of the expression of Ad also seems to be under the

Vol. 61(4): 349 - 375, 2020 
influence of iron, since transcription induction of ap65-1 (adhesion protein 65,000) was reported to be regulated, via certain iron-responsive DNA elements (e.g., AGATAACGA) (85). The Ad family appears to be regulated at several levels. These findings suggest that adhesion of $T v$ facilitates efficient cytotoxicity toward mammalian cells and probably involves complex interactions similar to the situation for other cell-cell contacts such as leukocytes (86). Additional parasite molecules with functional carbohydrate groups, distinct from Ad, appear to be involved in the adhesion of Tv to VEC (86), although the precise roles of the molecules in parasite adhesion and $\mathrm{CE}$ are not known. Little is known about the host cell receptors to which parasite adhesion molecules bind; although there is some evidence that laminin may be a target for trichomonad adhesion (87).

\section{Hydrolases}

A variety of hydrolases have been described in Tv, with cysteine proteinases being particularly prevalent. Ranging from 20 to $110 \mathrm{kDa}$, several of these lower molecular mass proteinases are released from the Trichomonads (88-90). There has been described other To products such as celldetaching factors which are released by the parasite $(91,92)$; it is known that some of them do have trypsin-like activity. These factors are active on human cells, causing them to detach. The release of cell-detaching factors and proteinases from To clearly implies that these parasite products could degrade proteins such as laminin, vitronectin, and other components of the extracellular matrix, thus effecting the release of host cells from tissue. In addition, the levels of secretory leukocyte proteases inhibitor in patients with $T$ v infections are significantly lower than those in uninfected patients $(93,94)$, The substrate specificity and structure of some of the proteinases of $T v$ are now being determined (88). Proteinases with lower molecular masses are released from the parasite; proteinases of 25,27 and $34 \mathrm{kDa}$ specifically hydrolyzed synthetic substrates with arginine-arginine residues, whereas other proteinases have activity over a wide substrate range $(88,90)$.

\section{Cytotoxic molecules}

Evidence suggests that To may produce molecules that are delivered to target cells and mediate cytotoxicity through damage of the target cell plasma membrane. One of these molecules creates pores in erythrocyte membranes as detected by electron microscopy (95), thus displaying perforin-like activity (96). An additional membrane-attacking molecule has recently been detected in Tv, $a$ lytic factor (LF) is released by $T v$ that can destroy nucleated cells and erythrocytes and specifically degrades phosphatidylcholine, suggesting that it is a phospholipase $A_{2}$ (97).

\section{Other molecules}

The importance of the thioredoxin system as one of the major antioxidant defense mechanisms in trichomonads, was confirmed by showing that the parasite responds to environmental changes, resulting in increased oxidative stress by up-regulating thioredoxin and thioredoxin peroxidases levels (88).

\section{Viruses}

Another factor that could increase its virulence is the presence of concomitant viruses (98). In 1985 it was first observed that a virus-like particles infected the protozoans, and were later recognized as being components of a double-stranded RNA (dsRNA) virus infecting the protozoans (99-101)]. To virus (TvV) is a non-segmented, 4.5-5.5 kilo-base pair (kbp), They are a dsRNA virus belonging to the genus Trichomonaviruses and to the viral family Totiviridae (102). TvV is encased within an 85 kilodalton major viral protein capsid arranged in the shape of a 120 -subunit icosahedral and is closely associated with the Golgi complex (103). TvVs use a viral RNA-dependent RNA polymerase to replicate its genetic material. TvVs affect the 
total protein expression of $T v$, and especially the expression of eysteine proteinases and the immunogenic protein $\mathrm{P} 270$, which are linked to cytotoxicity, cytoadherence, degradation of basement membrane of epithelium and host immune evasion $(78,98,104,105)$. TrVs can be divided into four different viral strains that have the ability to co-infect $T$ v at the same time: TvV1, TvV2, TvV3, and TvV4 (106). Each TvV strain has different effects on various aspects of $T v$ pathogenesis. TvV1 and TVv2 have been linked to genital symptom severity, while TvV2 and TvV3 are involved in the up-regulation of the surface expression of P270, cysteine proteinases and other virulence factors of $T v$ that help the $T v$ evasion from the host's immune response. The role of TvV4 has yet to be elucidated $(98,106,107)$. However, TvVs are considered to be well adapted to $T v$ such that they cause few if any deleterious effects in the protozoan and maintain a largely non-cytopathic and persistent infection (102).

Despite their non-lytic life style, infection of $T v$ by the dsRNA viruses causes the up-regulation of synthesis and surface expression of a highly immunogenic protein, P270 $(104,108)$. The presence of dsRNA viral infection of $T v$ is also associated with differential qualitative and quantitative expression of cysteine proteinases (78). Cysteine proteinases are linked with $T v$ cyto-adherence to vaginal epithelium, cytotoxicity, and degradation of basement membrane components (109). Two Tos surface proteinases bind to host epithelial cells and are related to levels of cytoadherence and cytotoxicity $(109,110)$. Thus, dsRNA viruses induce various phenotypic changes that may impact $T$ v virulence (78). Type 1 is the termed used to name virus negative $T v$ and type 2 for $T v$ positive to virus (108). The biological significance of $T v$ infection by TvVs remains poorly understood. It appears that $\mathrm{TvV}$ infection is generally a noncytopathic phenomenon that leads to stable, persistent infections of the protozoan host without an extra-cellular transmission phase (111). Transmission of
TvV occurs during cell division and possibly also during mating (112). Infection of Tv by TvVs could modulate the pathogenicity and virulence of Tv infections of the human genital mucosa (106). The percentage of TvVsinfected-Tos ranged from a low of 30\% (100) to a high of $100 \%$ (113). Graves et al. (99) reported a $40 \%$ of Tvs infected by TvVs. Wendel et al. (108) and Graves et al. (99) found that the Trs infected by TvVs were older (median age 38 years). These authors $(99,108)$ hypothesized that older women with $T$ v have less immune surveillance against TvV. However, Heidary et al. (114) did not find an association between $\mathrm{TvV}+$ isolates and older age. Thus, the relationship between TvV positivity and older age remains controversial, and additional studies are needed.

\section{Inflammation}

Epithelial cells act as a connector in a host-microbe communications network, building signal transduction connections between luminal microbes and the host. The epithelial cells act as sensors for the microbes and as providers of signal to immune cells to activate inflammatory and immune responses (115). Twu et al. (116) demonstrate that $T v$ exosomes fuse with and deliver their contents to host cells and modulate host cell immune responses. In addition, they showed that (116) parasite exosomes act to modulate host:parasite interactions and promote exosomes in promoting parasite:parasite communication and host cell colonization. Lin et al. (115) showed that there are seven cytokines expressed in the Tv infection; among them, is IL-8. A few days after the human become infected by $T v$, there is a degeneration of the vaginal epithelium, followed by leukocytic neutrophil infiltration that is associated with abundant vaginal discharge and intensely inflamed vaginal tissues. However, little is known about the early mechanism of how neutrophils accumulate or how epithelial cells mediate the initial inflammatory response upon $T v$ infection. Fichorova et al. (48) have provided evi- 
dence for an early involvement of chemokine production by epithelial cells that occurs in response to nontoxic doses of LPG and precedes cytotoxic effects. Interleukine-8 (IL8 ) is known to govern polymorphonuclear leukocytes localization and function (115) and is the major chemokine responsible for neutrophil recruitment to sites of tissue insult and inflammation (117-119), Shaio et al. $(120,121)$ reported the interleukin- 8 response to infection with $T v$ in human monocytes and neutrophils. Also, the same authors $(120,121)$ found the presence of IL- 8 in the vaginal discharge from patients with symptomatic trichomoniasis, providing evidence for involvement of IL-8 in the inflammatory response to To. Production of IL- 8 by monocytes and neutrophils stimulated by live trophozoites (122) or undefined $T v$ fragments has been reported (121). They $(121,122)$ have reported species-specific IL-8 production by human vaginal, ectocervical, and endocervical epithelial cells, in response to a chemically defined $T$. vaginalis constituent, purified T. vaginalis LPG. Increased IL-8 levels in genital tract secretions and amniotic fluid have been correlated with upper genital tract infections and preterm labor (123), suggesting that To IL-8 up-regulation may underlie the mechanisms linking trichomoniasis with preterm labor.

It has been hypothesized that the production of IL-8 during To infection may be secondary to the cytopathic effects and the release of the early response pro-inflammatory cytokines: Tumor Necrosis Factor-alfa (TNF- $\alpha$ ) and Interleukine-1beta (IL-1 $\beta$ ), by damaged epithelial cells. Fichirova et al. (48) demonstrated that IL- 8 is secreted by the cervical and vaginal epithelial cells, with no storage of significant IL-8 amounts in the epithelial cytoplasm. On the other hand, large intracellular stores of IL-1 and some small amounts of TNF- $\alpha$ are present in these cells and released once the membrane rupture and cell death (48). TNF- $\alpha$ and IL-1 $\beta$ induce the nuclear factor kappa-light-chain-enhancer of activated $B$ cells (NF-kB) activation via TNF receptor I and IL-1 receptor I, respectively, and also may act as toll-like receptor agonists in the reproductive tract epithelial cells $(119,124)$. The notion of the primary role of IL-1 $\beta$ and TNF- $\alpha$ in the TV-induced inflammatory response has found indirect support in the evidence of increased cervico-vaginal levels of these cytokines under pathological conditions commonly associated with trichomoniasis, e.ǵ., vaǵinitis, bacterial vaǵinosis, HIV-1 infection, and preterm labor (125). However, Fichirova et al. (48) showed that LPG stimulates a significantly increased IL-8 production in the absence of cell toxicity and at low baseline levels of endogenous IL-1 $\beta$ and TNF- $\alpha$. These findings suggest a direct recognition rather than a secondary cytopathic or host factor-mediated signaling effect of $T v$ LPG and support the hypothesis that the chemokine response to $T v$ may be initiated via LPG interaction with VEC surface receptors. Although these results indicate that LPG can trigger responses directly in VECs, and that this effect does not discard LPG interaction with leukocytes, such as macrophages, during the subsequent inflammatory response that may occur by other mechanisms and have a potent contribution to the pathogenesis of trichomoniasis. Fichorova et al. (48) mentioned that the MIP-3 production could play an important role in the immune response to $T v$ infection in the VECs. MIP- $3 \alpha$ is known to recruit Langerhans-like CD34 progenitor dendritic cells (DCs) to the site of inflammation, by guiding them as they traverse the lamina propia on their way to the epithelial surface, a journey which precedes their maturation (126). Also, Fichorova et al. (48) found that LPG-induced IL-8 and macrophage inflammatory protein-3 (MIP-3) $\alpha$ production by the VECs is, at least, partially MyD88 independent. This eytoplasmic adaptor protein MyD88 is essential for rapid NF-kB activation and cytokine production in response to multiple TLR ligands including LPS (127). The MyD88-independent activation via TLR is important for DC maturation (128). Fichorova et al. (48) have presented evidences of the 
major role of Tv LPG in the pathogenesis of the mucosal inflammatory reaction and suggested its modulatory role in the innate host immune response through selective speciesspecific cytokine up-regulation and multiple signaling pathway. Lin et al. (115) found that the vascular endothelial growth factor Beta (VEGF- $\beta$ ) is induced in human vaginal and ectocervical cells infected with To. According to these results, it is reasonable to assume that the disruption of host cell pathogenesis may be caused by these cytokines. Another cytokine which increased expression level, BMP- 2 is a member of the TGF- $\beta$ superfamily, playing an important role in the embryonic development, suppression of the immune response, and differentiation and proliferation of tissues and cells. Fichorova et al (48) have provided evidence that the major role of Tv LPG in the pathogenesis of the mucosal inflammatory reaction and suggests its modulatory role in the innate host immune response through selective species-specific cytokine up-regulation and multiple signaling pathways.

\section{Host response and immunology}

The actual understanding of immunity to To has come from observations of responses in human patients and experimentation using in vitro models and animal models of the related species, T. foetus. Natural infection seems to produce immunity that is only partially protective, since reinfection of patients can be $30 \%$ on follow-up (86). As it was mentioned before, most of Tv infection is often asymptomatic and recurrent, despite the presence of specific antibodies, suggesting the importance of the innate immune defense. To adhesion proteins, cysteine proteases, and the major parasite LPG play distinct roles in the pathogenesis and evasion of host immunity. LPG plays a key role in the parasite adherence and signaling to human vaginal and cervical epithelial cells, which is at least in part mediated by galectins. The epithelial cells respond to To infection and purified LPG by selective up- regulation of pro-inflammatory mediators. At the same time, To triggers an immunosuppressive response in monocytes, macrophages, and dendritic cells (117).

\section{Evidence and mechanism}

Antibody responses during $\mathrm{Tv}$ infection have been shown to occur in infected patients by several types of immunoassays (129). Infection in humans produces parasite-specific antibodies in the reproductive tract and, in most instances, circulating antibodies in the serum. There is also evidence of lymphocyte priming as detected by antigen-specific proliferation of peripheral blood mononuclear cells (130). Natural infection with To results in priming of acquired immune responses. The precise protective effects of parasitespecific immunity has not been so simple. In vitro analyses of the effects of serum-derived antibodies and monoclonal antibodies to surface antigens have identified anti-adhesin antibodies that block the adhesion of To to various human cell lines, such as HeLa (131), and to VECs (51). However, proof of the protective nature of antibodies in eliminating infection or limiting pathogenesis in vivo has been difficult because of lack of an adequate experimental-animal model for vaginal infection studies.

\section{Targets of acquired immunity}

The presence of parasite-specific immunoglobulin G (132) and immunoglobulin A (133) responses, also indicates priming of helper $\mathrm{T}$ cells, although the relevant antigens and the exact effects of antibodies on the parasites are unknown. One obvious target of protective antibody could be the adhesin molecules used by the parasite to facilitate close contact to host cells, a process previously shown to lead to efficient host cell destruction (134). The molecular basis of adhesion of $T v$ has been investigated, and four antigenic surface molecules have also been implicated in the adhesion of $T v$ to VECs; their expression is being up-regulated during attachment to host cells (75). 
Antibodies to these molecules protected target cells from parasite-mediated cytotoxicity (75), suggesting that anti-adhesion immune responses could be important in vivo protection against the pathogenic effects of Tv. However, actual understanding of immunity to $T v$ remains unclear. It is not known whether acquired immune responses are required for protection and, if it is true what role is played by acquired immunity in containing or eliminating infections (88). There is not a strong protective immunity after a natural infection in humans (88).

\section{Clinical features}

The majority of women (85\%) (135) and men (77\%) (136) with $T v$ are asymptomatic. One third of asymptomatic women become symptomatic within six months (21). Among symptomatic men, symptoms include urethral discharge and dysuria. Among symptomatic women, common sites of infection include the vagina, urethra and endocervix. Symptoms include vaginal discharge (which is often diffuse, malodorous, yellow-green), dysuria, vaginal and/or vulvar itching, vulvar irritation, vaginal odor and abdominal pain. The normal vaginal $\mathrm{pH}$ is 4.5 , but with $T$ v infection increases this markedly, often to $>5(21,31,32)$. Colpitis macularis or strawberry cervix (microscopic, punctate haemorrhages in the cervix) is seen in about 2-5 $\%$ of women, though with colposcopy this rises to nearly $50 \%(137,138)$ and the cervix becomes erythematosus, edematous, fragile and bleeds easily (139). Other complications include infection of the adnexa, endometrium, Skene and Bartholin glands. In men, it can cause epididymitis, prostatitis, and decreased sperm cell motility (140). When symptoms arise, the most common complaint among women diagnosed with $T v$ is vaginal discharge, presented in more than $50 \%$ of cases, followed by pruritus or dysuria (139). The vaginal discharge is a classical signal of trichomoniasis and it is due to intense leukocytic infiltration within the genital tract because of the death of epi- thelial cells, which promotes inflammation and leads to an increased number of polymorphonuclear leukocytes in the vaginal fluid (140). It is important to highlight that the infection symptoms are cyclic and more intense around the menses period because of the effect of iron on parasite pathogenesis (21). Studies have shown an association between $T v$ and vaginitis, cervicitis, urethritis, bacterial vaginosis, candidiasis, herpes simplex virus type- 1 and type-2, chlamydia, gonorrhea, syphilis, human papillomavirus (HPV) and human immunodeficiency virus $[32,37)$. In addition, endometritis, adnexitis, pyosalpinx, and atypical pelvic inflammatory disease are related to $T v$ infection (117). Trichomoniasis may also affect the pregnancy course, causing low birth weight, premature rupture of membranes and preterm delivery (141). There are some evidence that $T v$ infection can be transmitted vertically leading to cases of vaginal and respiratory infections in neonates $(142,143)$. Mann et al. (144) showed an association between maternal $T v$ infection and intellectual disability in children.

\section{Inflammation and tumorigenesis}

Over the past two decades, our understanding of inflammation in tumorigenesis has led to the identification of a number of molecules that are strongly linked to the development of human cancers (145-147). Like tumorigenesis, tumor-promoting inflammation and tumor-associated inflammation (TAI) are the phenotypic product of a complex set of cellular and molecular interactions that result in an imbalance in the local microenvironment that is most analogous to an unresolved 'wound-healing' response (147).

A number of the cellular and molecular mechanisms involved in inflammation-induced tumor initiation, promotion and progression are now well described ( Table III). In recent years, strong evidence from many epidemiological and experimental studies have demonstrated that inflammation also 


\section{TABLE III}

MOLECULE, GELLS AND TISSUE ALTERATIONS OBSERVED WITH CHRONIC INFLAMMATION AND TUMOR PROMOTING CONSEQUENCE.

\begin{tabular}{l}
$\begin{array}{l}\text { Genomic instability, chromosome remodeling, epigenetic changes and altered gene and miRNA } \\
\text { expression. }\end{array}$ \\
\hline Altered post-translational modification, activity and localization of cell proteins. \\
\hline Altered cell metabolism. \\
\hline $\begin{array}{l}\text { Induction of cell growth and anti-apoptotic signals } \rightarrow \text { uncontrolled cell growth and retention of } \\
\text { cells with damaged genomes. }\end{array}$ \\
\hline $\begin{array}{l}\text { Vasodilation, leakage of the vasculature and infiltration of leukocytes } \rightarrow \text { disrupted tissue integrity } \\
\text { and altered microenvironment and immunosuppression and recruitment of myeloid suppressor } \\
\text { cells. }\end{array}$ \\
\hline $\begin{array}{l}\text { Altered cell polarity } \rightarrow \text { disturbance in stroma/epithelial tissue matrix and loss of differentiation } \\
\text { signals. }\end{array}$ \\
\hline Tissue necrosis $\rightarrow$ neovascularization and hypoxia. \\
\hline Induction of matrix metalloproteinases $\rightarrow$ invasiveness and spread. \\
\hline
\end{tabular}

plays an important role in the development of CIN and cervical cancer (148). Cervical inflammation may be associated and may be a cofactor in high-grade cervical lesions in women infected with oncogenic HPV. In other cancer types, independent of the causal agent, chronic inflammation exposes the tissue to constant genotoxic damages. In cervical cancer, chronic inflammation added to the initial changes caused by high-risk HPV, may contribute to viral persistence and disease proǵression $(149,150)$.

\section{Acute versus chronic inflammation and carcinogenesis}

Acute inflammation has two balanced and biologically opposing effector arms or mechanisms: 1 . a pro-apoptotic or tumoricidal and 2. a wound healing or pro-tumorigenic relationship model, where immune cells participate with the non-immune cells in the local environment (e.g. epithelial, vasculature and neuronal) $(151,152)$. Local or systemic adaptive immune responses (cell-mediated and humoral immunity) are activated and mobilized by selective signal- ing between the activated innate immune effector cells (e.g. macrophages and mast cells) and their counterparts in the adaptive immune system (e.g. T and B lymphocytes). In the acute inflammation, immune cells possess properties specialized that allowing them to recognize and eliminate intrinsic or extrinsic foreign elements and that injure or damage host tissue (acute phase). In the intermediate or resolution phase response, the immune cells function to resolve inflammation and repair the damaged tissue. Unresolved and persistent inflammation has been described as the loss of, or deregulation in the balance between both mechanisms. The role of persistent inflammation as a contributing factor in tumorigenesis is well accepted and, in many cancers, thought to be a necessary component. Examples include a causal relationship between inflammation and infectious agent-associated cancers [e.g. hepatitis B and C virus (liver), human papilloma virus (e.g. cervix, anal) and the bacterium Helicobacter pylori (stomach)]. The relationship between cancer and inflammation is also supported by the elevated risk 
of cancer in chronic inflammatory conditions, such as colitis-associated colorectal cancer. Importantly, the cause-effect relationship between inflammation and cancer is a challenging concept as it implies that inflammation precedes the processes. However, current evidence widely suggests that in the case of cancer, which is a multi-step and complex process, inflammation is an integral component of the overall pathogenesis of disease at the microenvironment level that not only contributes in a causal way but also supports a permissive state for tumors to grow (145). It is important to recognize that TAI in solid tumors is itself a complex pathologic process, with contributions from classic immune cells as well as poorly characterized, cancer-associated fibroblasts and the epithelial tumor cell compartment (151). As it was mentioned before, $T v$ is infected by four different types of dsRNA viruses. When the parasite dies, releases its viral load within the human vagina. This could explain why symptoms can worsen upon suceessful antibiotic treatment and why $T v$ infected by the virus contribute to increase the inflammatory response and the virulence (153).

Trichomonas vaginalis and cervical cancer Epidemiology of cervical cancer

In 2018, according to the International Agency for Research on Cancer/Globocan (IARC), the cervical cancer (CG) was the ninth more frequent type of eancer worldwide, including both sexes, with 569,847 new cases, representing an incidence of $3.2 \%$ among all the cancers, and caused 311,365 deaths (incidence:3.3\%), being the ninth deadliest cancer worldwide (IRC). CG represents the second most common female cancer, after breast cancer, worldwide (154). The Pan-American Heath Organization/ World Health Organization (PAHO/WHO) (155) reported 72,000 new cases of $\mathrm{CC}$ and almost 34,500 deaths in the American continent during 2018. The mortality rate was three times higher in Latin-America and the Caribbean area than in North-America (155).
It is well known that the development of pre-malignant and malignant cervical lesions is multi-factorial. One of this most important factor is HPV, especially the high risk-HPV (hr-HPV) type 16 and 18, as the main etiological agent. Other risk factors have been identified in various cross-sectional and prospective cohort studies, including number of sexual partners (lifetime and recent), early onset of first intercourse, promiscuos partner, smoking, long-term use of oral contraceptives, multiparity, vaginal infection, malnutrition, certain dietary deficiencies, immunosuppressive conditions such HIV, and chronic inflammation due to co-infection with others microorganisms Ct, HSV-2, Ca, gonorrhea, BV, Ureaplasma urealyticum, Ureaplasma parvum, and To (156-158). Different authors $(159,160)$ have mentioned that the association among these STIs and cervical lesions may be related to their inflammation effects. Infection with hrHPV plays a central role in cervical carcinogenesis. Epidemiological and molecular investigations have shown unequivocally that hr-HPV infection is the main causal factor in initiating the progressive transformation that leads to cervical intraepithelial neoplasia and to cervical cancer (161-163). Many reports have demonstrated that HPV infections are mostly transitory and that only a small percentage of infections persist and may progress to dysplastic lesions: type-specific HPV persistence is the strongest risk factor for cervical cancer (164). The reasons for the variable natural history remain poorly understood, but it has been generally accepted that different cofactors are involved in the development of dysplasia in HPV infected women. Factors, such as specific HPV genotype, viral load, and co-infection with more HPV types, are likely to be involved in the progression to precancerous cervical lesions (164-167). In addition, environmental co-factors mentioned before have also been investigated as potentially involved in the disease process (168-170). The sexually transmitted pathogens were reported to in- 
teract with HPV as cofactors in the progression of eervical neoplasias. For instance, Ct and $T v$ were proved to be positively correlated with hr-HPV persistent infection (171).

\section{Trichomonas vaginalis/HPV/cervical intraephitelial neoplasia}

Another important issue regarding complications of trichomoniasis in women is its involvement with an increased risk of cervical cancer. Some studies have pointed $T v$ as a predictor for cervical neoplasia since there is a high relative risk of preinvasive lesion and invasive cancer (CIN) $(8,172)$. As it was mentioned before, the cervical epithelium is a protective barrier which is disrupted by inflammation produced by $T v$ infection, allowing the penetration of hr-HPV to the basement membrane $(8,159,163,172,173)$. As it was mentioned in this manuscript before, Goshi et al. (172) reported that the association of To with high grade CIN is because of the epithelial alteration and damage that characterize these conditions facilitate the proliferation of the organism. The cell mediated immunity generated against the invading organism involves recruitment of leucocytes in large numbers, which are associated with findings on cytology of smears. Further, the parasite often imbibes nutritious elements like fatty acids and iron by destruction of host red blood cells, which is caused by cytotoxic trypsin like substances called cell detaching factor, CDF and N-nitrosamines liberated during infection, which also promote the process of epithelial atypia and dysplasia. Vaginal $\mathrm{pH}$ rises during $T$ io infection, which allows the growth of the organism. To thrives on tissue debris and serous exudate and produces tissue damage that is extensive and atypical. Disease pathogenesis of $T v$ infection necessitates multitude of cross-communications involving viruses, bacteria, eukaryotes and human host (174). Gram et al. (175) mentioned that the infeetions by HPV and Tv play an important role in the pathogenesis or CIN and CC. Lazenby et al. (8) had found Tv using nucleic acid am- plification test (NAAT) to be associated with an increased risk of acquisition of high risk HPV (OR 4.2, 95\% C.I. 1.7-10.3). Donders et al. (176) demonstrated that HSIL cases where To was discovered, hr-HPV was present. Theses authors (176) found that women with ASC-US with To had no HPV (36\%). Although, the presence of To was higher in patients HPV negative/ASC-US compared to the group HPV positive (low and high risk)/ ASC-US patients. Tao et al. (177) found that TV infection is associated with CIN especially to high degree. They (177) mentioned that there is some epidemiological evidence to suggest that genital tract disease such as cervical inflammation might be linked to cervical cancer or high-grade lesions, and a significant association between cervical inflammation and HISL was identified in this study. To may act as a cofactor facilitating the development of eervical HPV infection to high-grade lesion and cervical cancer. Multiple studies have demonstrated an association between previous and current $T v$ infection and cervical dysplasia and human papillomavirus $(172,178)$. Fem et al. (179) found that women with HPV are more likely to be infected by other types of STIs. Also, they said $T v+$ women had an increased risk to get hr-HPV infection compared to negative To women. Yap et al. (180) found antibodies against $\mathrm{Tv}$ in $41.3 \%$ of patients with invasive $\mathrm{CC}$ compared with $5 \%$ in control group.

\section{CONCLUSION}

To is considered as the second most frequent STIs and the second most common cause of lower genital tract infection worldwide. Because To infection is highly prevalent in sexually active populations, it is now gaining greater recognition as an important source of reproductive morbidity and is clearly associated with significant public health problems. Also, To infection has the potential to increase the possibility for the acquisition and transmission of 
HIV, possibly HSV-2 and HPV. It has been independently associated with eancer, so it has been considered as a co-factor or factor for CC. Trichomoniasis is clearly associated with significant public health problems. The disease presentation is variable and diagnosis can be difficult with the most commonly used methods. Certain socio-demographic and behavioral risk factors may assist in predicting infection. A majority of women and a significant proportion of men with trichomoniasis are asymptomatic; these patients would thus escape detection and treatment under syndromic management recommendations. Control programs must work towards increased screening in order to have any effect on the burden of this disease. In recent years, many advances have been made in the epidemiology, diagnosis, and treatment of Tv. The focus of these efforts, however, has largely been on women. Although there are still many open questions regarding Tv's epidemiology, particularly in the context of facilitated HIV contagion and cancer, our understanding of To's pathogenesis made a large leap forward and the picture is becoming ever more complete. Finally, the Tv genome has remained as a fascinating field of study. So far, there have been four dsRNA viruses identified. This area opens a great and broad field for research about the virulence and its possible role as co-factor or factor in $\mathrm{CC}$ in the next years to come.

\section{REFERENCES}

1. Schwebke JR, Gaydos CA, Nyirjesy P, Paradis S, Kodsi S, Coopere CK. Diagnostic performance of a molecular test versus clinician assessment of vaǵinitis. J Clin Microbiol 2018; 56 (6) 1-13.

2. Report on global sexually transmitted infection surveillance, 2018. World Health Organization 2018. Available at:https:// www.who.int/reproductivehealth/publications/stis-surveillance-2018/en/. Reviewed on July 7, 2020.

3. 2015 STD Treatment Guidelines - Trichomoniasis - Updated diagnostic, treatment, and sereening recommendations for STDs. Center for Disease Control and Prevention. https://www.edc.gov/std/tg2015/trichomoniasis.htm. Review on July 07, 2020.

4. Spence D, Melville C. Vaginal discharge. BMJ 2007;335(7630):1147-1151. doi: 10.1136/bmj.39378.633287.80.

5. Núñez-Troconis J. Diaǵnóstico de la Tricomonas vaginalis en la mujer. Rev Chil Obstet Ginecol 2020; 85(2): 175-184.

6. Rowley J, Vander Hoorn S, Korenromp E, Low N, Unemo M, Abu-Raddad LJ, Chico RM, Smolak A, Newman L, Gottlieb S, Thwin SS, Broutet N, Taylor MM. Chlamydia, gonorrhoea, trichomoniasis and syphilis: global prevalence and incidence estimates, 2016. Bull World Health Organ 201;97(8):548-562.

7. Leitsch D. Recent Advances in the Trichomonas vaginalis Field. F1000Res. 2016;5:F1000 Faculty Rev-162.

8. Lazenby GB, Taylor PT, Badman BS,Mchaki E, Korte JE, Soper DE, Pierce, Young-Pierce J. An association between Trichomonas vaginalis and highh-risk human papillomavirus in rural Tanzanian women undergoing eervical eancer sereening. Clin Ther 2014;36(1):38-45.

9. Trichomoniasis. Sexually Transmitted Infections. Pan-American Health Organization.Available at https://www.paho.org/hq/ index.php?option $=$ com_content $\&$ view $=\mathrm{a}$ rticle\&id=14868:sti-trichomoniasis\&Item $\mathrm{id}=3670 \&$ lang $=$ en. Reviewed on July 07, 2020.

10. STD Surveillance 2018 - Other Sexually Transmitted Diseases - Trichomoniasis (October 8, 2019). Centers of Diseases of Control and Prevention. Available at: https://www.edc.gov/std/trichomonas/ stats.htm. Reviewed on July 7, 2020.

11. Salomon MC, Martinez N, Delgado D, Gonzalez Arra C, Bittar V, Gonzalez N. Trichomonas vaginalis prevalence in sex workers. Medicina 2011;71(5): 429-431.

12. Neira OP, Correa LLA, Muñoz SN, Tardío OMT, Carabelli FM. Frecuencia de infeeción por Trichomonas vaginalis en atención primaria de salud. Rev Chil Obstet Ginecol 2005; 70:147-151.

13. Leon SR, Konda KA, Bernstein KT, Pajuelo JB, Rosasco AM, Caceres CF, Coates 
TJ, Klausner JD. Trichomonas vaginalis infection and associated risk factors in a socially-marginalized female population in coastal Peru. Infect Dis Obstet Gynecol 2009; 2009:752437.

14. Luppi CG, de Oliveira RL, Veras MA, Lippman SA, Jones H, de Jesus CH, Pinho AA, Ribeiro MC, Caiaffa-Filho H. Early diagnosis and correlations of sexually transmitted infections among women in primary care health services. Rev Bras Epidemiol 2011;14(3): 467-477.

15. Grama DF, Casarotti Lda S, Morato MG, Silva LS, Mendonea DF, Limongi JE, Viana Jda C, Cury MC. Prevalence of Trichomonas vaginalis and risk factors in women treated at public health units in Brazil: a transversal study. Trans R Soc Trop Med Hyg 2013;107(9): 584-591.

16. Ochoa DA, Filho RA, Marino JM, dos Santos CM. Hidden sexually transmitted infections among women in primary eare health services, Amazonas, Brazil. Int J Std AIDS 2014;25(12): 878-886.

17. Núñez M, Flores T, Calchi M, Páez B. Epidemiología, clínica y diagnóstico de Trichomonas vaginalis en mujeres aparentemente sanas del municipio Maracaibo. Estado Zulia, Venezuela. Kasmera 1997; 25(2):99-120.

18. Menezes CB, Frasson AP, Tasea T. Trichomoniasis - are we giving the deserved attention to the most common non-viral sexually transmitted disease worldwide? Microb Cell 2016;3(9):404-419.

19. Patel EU, Gaydos CA, Packman ZR, Quinn TC, Tobian AAR. Prevalence and correlates of Trichomonas vaginalis infection among men and women in the United States. Clin Infect Dis 2018;67(2):211-217.

20. Maritz JM, Land KM, Carlton JM, Hirt RP. What is the importance of zoonotic trichomonads for human health? Trends Parasitol 2014; 30(7): 333-341.

21. Petrin D, Delgaty K, Bhatt R, Garber G. Clinical and microbiological aspects of Trichomonas vaginalis. Clin Microbiol Rev 1998; 11(2): 300-317.

22. Zhang ZF, Beğg CB. Is Trichomonas vağinalis a cause of cervical neoplasia? Results from a combined analysis of 24 studies. Int J Epidemiol 1994; 23(4): 682-690.
23. Viikki M, Pukkala E, Nieminen P, Hakama M. Gynaecological infections as risk determinants of subsequent cervical neoplasia. Acta Oncol 2000; 39(1): 71-75.

24. Silver BJ, Guy RJ, Kaldor JM, Jamil MS, Rumbold AR. Trichomonas vaginalis as a cause of perinatal morbidity: a systematic review and meta-analysis. Sex Transm Dis 2014; 41(6): 369-376.

25. Cotch MF, Pastorek JG, Nugent RP, Hillier SL, Gibbs RS, Martin DH, Eschenbach DA, Edelman R, Carey JC, Regan JA, Krohn MA, Klebanoff MA, Rao AV, Rhoads GG. Trichomonas vaginalis associated with low birth weight and preterm delivery. The vaginal infections and prematurity study group. Sex Transm Dis 1997;24(6): 353- 360.

26. Grodstein F, Goldman MB, Cramer DW. Relation of tubal infertility to history of sexually transmitted diseases. Epidemiol Rev 1997;137(5): 577-584.

27. Gimenes F, Souza RP, Bento JC, Teixeira JJ, Maria-Engler SS, Bonini MG, Consolaro ME. Male infertility: a public health issue caused by sexually transmitted pathogens. Nat Rev Urol 2014; 11(12): 672-687.

28. MeClelland RS, Sangare L, Hassan WM, Lavreys L, Mandaliya K, Kiarie J, Ndinya-Achola J, Jaoko W, Baeten JM. Infection with Trichomonas vaginalis increases the risk of HIV-1 acquisition. J Infect Dis 2007;195(5): 698-702.

29. Poole DN, McClelland RS. Global epidemiology of Trichomonas vaǵinalis. Sex Transm Infect 2013;89(6): 418-422.

30. Lehker MW, Alderete JF. Biology of trichomonosis. Curr Opin Infect Dis 2000;13(1): 37-45.

31. Kissinger P. Epidemiology and treatment of trichomoniasis. Curr Infect Dis Rep 2015;17(6):484.

32. Kissinger P. Trichomonas vaginalis: a review of epidemiologic, clinical and treatment issues. BMC Infect Dis 2015;15:307. P

33. Hirt RP. Trichomonas vaginalis virulence factors: an integrative overview. Sex Transm Infect. 2013 Sep;89(6):439-43. doi: 10.1136/sextrans-2013-051105. Epub 2013 May 21.

34. Harp DF, Chowdhury I. Trichomoniasis: evaluation to execution. Eur J Obstet Gynecol Reprod Biol 2011; 157(1):3-9. 
35. Lindmark DG, Müller M. Hydrogenosome, a cytoplasmic organelle of the anaerobic flagellate Tritrichomonas foetus, and its role in pyruvate metabolism. J Biol Chem 1973; 248(22): 7724-7728.

36. Pustan L, AilieseioI O, Dunca S. Trichomonas vaginalis, a risk factor for cervical cancer. Analele Ştiinţifice ale Universităţii, Alexandru Ioan Cuza", Secţiunea Genetică şi Biologie Moleculară, TOM XI, 2010. Paǵe: 107-112.

37. Leitsch D. Recent advances in the Trichomonas vaginalis field. F1000Res. 2016;5:F1000 Faculty Rev-162.

38. Carlton JM, Hirt RP, Silva JC, Delcher AL, Schatz M, Zhao Q, Wortman JR, Bidwell SL, Alsmark UCM, Besteiro S. Draft genome sequence of the sexually transmitted pathogen Trichomonas vaginalis. Science 2007;315:207-212.

39. Krieger JN. Trichomoniasis in men: old issues and new data. Sex Transm Dis 1995;22(2):83-96.

40. Afzan MY, Suresh K. Pseudocyst forms of Trichomonas vaginalis from cervical neoplasia. Parasitol Res 2012;111(1):371-381.

41. Pereira-Neves A, Ribeiro KC, Benchimol M. Pseudocysts in trichomonads-new insights. Protist 2003;154(3-4):313-329.

42. Goodman RP, Ghabrial SA, Fichorova RN, Nibert ML. Trichomonasvirus: a new genus of protozoan viruses in the family Totiviridae. Arch Virol 2011; 156(1): 171-179.

43. Goodman RP2, Freret TS, Kula T, Geller AM, Talkington MW, Tang-Fernandez V, Suciu O, Demidenko AA, Ghabrial SA, Beach DH, Singh BN, Fichorova RN, Nibert ML. Clinical isolates of Trichomonas vaginalis concurrently infected by strains of up to four Trichomonasvirus species (Family Totiviridae). J Virol 2011;85(9):4258-4270.

44. Singhh M, Beri D, Nageshan RK, Chavaan L, Gadara D, Poolary M, Subramaniam S, Tatu U. A secreted Heat shock protein 90 of Trichomonas vaginalis. PLoS Negl Trop Dis 2018;12(5):e0006493.

45. Arroyo R, Engbring J, Alderete JF. Molecular basis of host epithelial cell recognition by Trichomonas vaginalis. Mol Microbiol 1992;6(7):853-862

46. Ferguson MA. The structure, biosynthesis and functions of glycosylphosphatidylinositol anchors, and the contribu- tions of trypanosome research. J. Cell Sci 1999;112:2799-2809.

47. Guha-Niyogi A, Sullivan DR, Tureo SJ. Glycoconjugate structures of parasitic protozoa. Glycobiology 2001;11:45R-59R.

48. Fichorova RN, Trifonova RT, Gilbert RO, Costello CE, Hayes GR, Lucas JJ, Singh BN. Trichomonas vaginalis lipophosphoǵlycan triggers a selective up-regulation of cytokines by human female reproductive tract epithelial cells. Infect Immun 2006; 74:5773-5779.

49. Singhh BN. Lipophosphoǵlycan-like ǵlycoconjugate of Trichomonas foetus and Trichomonas vaginalis. Mol. Biochem. Parasitol 1993;57:281-294.

50. Singh BN, Beach DH, Lindmark DG, Costello CE. Identification of the lipid moiety and further characterization of the novel lipophoshoglycan-like ǵlycoconjugates of Trichomonas vaginalis and Trichomonas foetus. Arch Biochem Biophys 1994; 309:273-280.

51. Gilbert RO, Elia G, Beach DH, Klaessig S, Singh BN. Cytopathogenic effect of Trichomonas vaginalis on human vaginal epithelial cells cultured in vitro. Infect Immun 2000;68(7):4200-4206.

52. Ryan CM, de Miǵuel N, Johnson PJ. Trichomonas vaginalis: current understanding of host-parasite interactions. Essays Biochem 2011;51:161-175.

53. Pereira-Neves A, Benchimol M. Phaǵocytosis by Trichomonas vaginalis: new insights. Biol Cell 2007; 99:87-101.

54. Hirt RP, Noel CJ, Sicheritz-Ponten T, Tachezy J, Fiori PL. Trichomonas vaginalis surface proteins: a view from the genome. Trends Parasitol 2007;23:540-547.

55. Engbring JA, Alderete JF. Characterization of Trichomonas vaginalis AP33 adhesin and cell surface interactive domains. Microbioloǵy 1998;144:3011-3018.

56. Garcia AF, Alderete J. Characterization of the Trichomonas vaginalis surface-associated AP65 and binding domain interacting with trichomonads and host cells. BMC Microbiol 2007;7:116.

57. Alderete JF, Millsap KW, Lehker MW, Benchimol M. Enzymes on microbial pathogens and Trichomonas vaginalis: molecular mimicry and functional diversity. Cell Microbiol 2001; 3:359-370. 
58. Addis MF, Rappelli P, Fiori PL. Host and tissue specificity of Trichomonas vaginalis is not mediated by its known adhesion proteins. Infect Immun 2000;68:4358-4360.

59. Ardalan S, Lee BC, Garber GE. Trichomonas vaginalis: the adhesins AP51 and AP65 bind heme and hemoglobin. Exp Parasitol 2009;121:300-306.

60. Lama A, Kucknoor A, Mundodi V, Alderete JF. Glyceraldehyde-3-phosphate dehydrogenase is a surface-associated, fibronectinbinding protein of Trichomonas vaginalis. Infect Immun 2009;77:2703-2711.

61. Warton A1, Honigberg BM. Lectin analysis of surface saccharides in two Trichomonas vaginalis strains differing in pathogenicity. J Protozool 1980;27:410-419.

62. Warton A, Kon VB, Papadimitriou JM. Demonstration of concanavalin $\mathrm{A}$ and wheat germ aǵglutinin-binding sites on the Trichomonas vaǵinalis surface coat using lectin-gold particle conjugates. J Electron Microse (Tokyo) 1888;37:134-140.

63. Bastida-Corcuera FD, Okumura CY, Colocoussi A, Johnson PJ. Trichomonas vaginalis lipophosphoǵlycan mutants have reduced adherence and cytotoxicity to human ectocervical cells. Eukaryot Cell 2005; 4:1951-1958.

64. Okumura CYM, Baum LG, Johnson PJ. Galectin-1 on cervical epithelial cells is a receptor for the sexually transmitted human parasite Trichomonas vaginalis. Cell Microbiol 2008;10:2078-2090.

65. Singh BN4, Hayes GR, Lucas JJ, Sommer U, Viseux N, Mirgorodskaya E, Trifonova RT, Sassi RR, Costello CE, Fichorova RN. Structural details and composition of Trichomonas vaginalis lipophosphoǵlycan in relevance to the epithelial immune function. Glycoconj J 2009;26:3-17.

66. Alderete JF2, Garza GE. Specific nature of Trichomonas vaginalis parasitism of host cell surfaces. Infect Immun 1985;50:701708.

67. de Miguel N, Lustig G, Twu O, Chattopadhyay A, Wohlschlegel JA, Johnson PJ. Proteome analysis of the surface of Trichomonas vaginalis reveals novel proteins and strain-dependent differential expression. Mol Cell Proteomics 2010;9:1554-1566.
68. Bonilha VL, Ciavaglia Mdo C, de Souza W, Costa e Silva Filho F. The involvement of terminal carbohydrates of the mammalian cell surface in the cytoadhesion of trichomonads. Parasitol Res 1995;81:121-126.

69. Noel CJ, Diaz N, Sicheritz-Ponten T, Safarikova L, Tachezy J, Tang P, Fiori PL, Hirt RP. Trichomonas vaginalis vast BspA-like gene family: evidence for functional diversity from structural organisation and transcriptomics. BMC Genomics 2010;11:99.

70. Lin WC, Chang WT, Chang TY, Shin JW. The pathogenesis of human cervical epithelium cells Induced by Interacting with Trichomonas vaginalis. PLoS One. 2015;10(4):e0124087.

71. Kucknoor AS, Mundodi V, Alderete JF. The proteins secreted by Trichomonas vaginalis and vaginal epithelial cell response to secreted and episomally expressed AP65. Cell Microbiol 2007; 9 (11):2586-2597.

72. Kucknoor AS, Mundodi V, Alderete JF. Trichomonas vaginalis adherence mediates differential gene expression in human vaǵinal epithelial cells. Cell Microbiol 2005; 7 (6):887-897. doi: 10.1111/j. 14625822.2005.00522.x.

73. Koch S, Nusrat A. Dynamic regulation of epithelial cell fate and barrier function by intercellular junctions. Ann N Y Acad Sci 2009; 1165:220-227.

74. Lehker MW, Sweeney D. Trichomonad invasion of the mucous layer requires adhesins, mucinases, and motility. Sex Transm Infect 1999; 75(4):231-238.

75. Arroyo R, González-Robles A, Martínez-Palomo A, Alderete JF. Signalling of Trichomonas vaginalis for amoeboid transformation and adhesion synthesis follows cytoadherence. Mol Microbiol 1993;7(2):299-309.

76. Guenthner PC, Secor WE, Dezzutti CS. Trichomonas vaginalis-induced epithelial monolayer disruption and human immunodeficiency virus type 1 (HIV-1) replication: implications for the sexual transmission of HIV-1. Infect Immun 2005; 73(7):4155-4160.

77. Fiori PL 1, Rappelli P, Addis MF, Mannu F, Cappuceinelli P. Contact-dependent disruption of the host cell membrane skeleton induced by Trichomonas vaginalis. Infect Immun 1997; 65(12):5142-5148. 
78. Provenzano D, Khoshnan A, Alderete JF. Involvement of dsRNA virus in the protein composition and growth kinetics of host Trichomonas vaǵinalis. Arch Virol 1997; 142: 939-952.

79. Garcia-Tamayo J, Nuñez-Montiel JT, de Garcia HP. An electron microscopic investigation on the pathogenesis of human vaginal trichomoniasis. Acta Cytol 1978;22(6):447-455.

80. Garcia-Tamayo J, Nuñez-Montiel JT, de Garcia HP. Tricomoniasis vaǵinal humana: Estudio ultrastructural e histoquimico. Invest Clin 1972;13:2-14.

81. Heath JP. Behaviour and pathogenicity of Trichomonas vaginalis in epithelial cell cultures: a study by light and scanning electron microseopy. Br J Vener Dis 1981;57(2):106-117.

82. Nielsen MH, Nielsen R. Electronmicroseopy of Trichomonas vaginalis: Interaction with vaginal epithelium in human trichomoniasis. Acta Pathol Microbiol Scand (B) 1975;83:305-320.

83. Engbring $\mathbf{J}$, Alderete JF. Characterization of Trichomonas vaginalis AP33 adhesin and cell surface interactive domains. Microbiology 1998;144:3011-3018.

84. Mendoza-Lopez M, C. Becerril-Garcia L, Fattel-Facenda v, Avila-Gonzalez L, RuizTachiquin ME, Ortega-Lopez $\mathbf{J}$, Arroyo R. CP30, a cysteine proeinase involved in Trichomonas vaginalis cytoadherence. Infect Immun 2000;68:4907-4912.

85. Tsai C, Liu HW, Tai JH. Characterization of an iron-responsive promoter in the protozoan pathogen Trichomonas vaginalis. J Biol Chem 2002;277:5153-5162.

86. Fais S, Malorni W. Leukocycte uropod formation and membrane/cytoskeleton linkage in immune interactions. J Leukoc Biol 203;73:556-563.

87. Silva-Filho F, Kasai S, Nomizu M, Lopez LB, Melo-Braga MB, Rocha-Azevedo B, Petropolis DB, Horbach IS. How laminin-1 can be recognized by the protozoan parasite Tritrichomonas foetus: possible role played by the extracellular matrix glycoprotein in both cytoadhesion and cytotoxicity exerted by the parasite. Parasitol Int 2002;51:305-307.
88. Schwebke JR, Burgess D. Trichomoniasis. Clin Microbiol Rev 2004;17(4):794-803. doi:10.1128/CMR.17.4.794-803.2004.

89. Lockwood B1, North MJ, Scott KI, Bremner AF, Coombs GH. The use of a highly sensitive electophoretic method to compare the proteinases of trichomonads. Mol Biochem Parasitol 1987:24:89-95.

90. North M, Robertson CD, Coombs GH. The specificity of trichomonad proteinases analyzed using fluorogenic substrates and specific inhibitors. Mol Biochem Parasitol 1990; 39:183-194.

91. Garber GE, Lemchuk-Favel LT, Bowie WR. Isolation of a cell-detaching factor of Trichomonas vaginalis. J Clin Microbiol 1989;27:1548-1553.

92. Lushbaugh W, Turner AC, Gentry GA, Klykken PC. Characterization of a secreted cytoactive factor from Trichomonas vaginalis. Am J Trop Med Hyg 1989;41:18-28.

93. Draper D, Donohoe W, Mortimer L, Heine RP. Cysteine proteases of Trichomonas vaginalis degrade secretory leukocyte protease inhibitor. J Infect Dis 1998;178:815-819.

94. Draper D, Landers DV, Krohn MA, Hillier SL, Wieseneld HC, Heine RP. Levels of vaginal secretory leukocyte protease inhibitor are decreased in women with lower reproductive tract infections. Am J Obstet Gynecol 2000;183:1243-1248.

95. Fiori P, Rappelli P, Rocchigiani A, Cappuccinelli P. Trichomonas vaginalis haemolysis: evidence of functional pores formation on red cell membranes. FEMS Microbiol Lett 1993;13-18.

96. Fiori P, Rappelli MF, Addis MF. The flagellated parasite Trichomonas vaginalis: new insights into eytopathogenicity mechanisms. Microb Pathog 1999;1:149-156.

97. Lubick K, Burgess DE. Purification and analysis of phospho-lipaseA2-like lytic factor of Trichomonas vaginalis. Infect Immun 2004;72:1284-1290.

98. Graves KJ1, Ghosh AP, Kissinger PJ, Muzny CA. Trichomonas vaginalis virus: a review of the literature. Int J STD AIDS 2019;30(5):496-504.

99. Graves KJ2, Ghosh AP, Schmidt N, Augostini N, Secor WE, Schwebke JR, Martin DH, Kissinger PJ, Muzny CA. Tri- 
chomonas vaginalis virus among women with trichomoniasis and associations with demographics, elinical outcomes, and metronidazole resistance. Clin Infect Dis 2019;69(12):2170-2176.

100. Wang AL1, Wang CC. The double-stranded RNA in Trichomonas vaginalis may originate from virus-like particles. Proc Natl Acad Sci USA. 1986;83(20):7956-7960.

101. Wang AL, Wang CC. A linear double-stranded RNA in Trichomonas vaginalis. J Biol Chem 1985;260(6):3697-3702.

102. Goodman RP, Ghabrial SA, Fichorova RN, Nibert ML. Trichomonasvirus: a new genus of protozoan viruses in the family Totiviridae. Arch Virol 2011; 156(1): 171-179.

103. Parent KN, Takagi Y, Cardone G, Olson NH, Ericsson M, Yang M, Lee Y, Asara JM, Fichorova RN, Baker TS, Nibert ML. Structure of a protozoan virus from the human genitourinary parasite Trichomonas vaginalis. mBio 2013;4(2): e0056-13.

104. Khoshnan A, Alderete JF. Trichomonas vaginalis with a double-stranded RNA virus has upregulated levels of phenotypically variable immunogen mRNA. J Virol 1994;68(6):4035-4038.

105. He D, Pengtao G, Ju Y, Jianhua L, He L, Guocai $\boldsymbol{Z}$, Xichen $Z$. Differential protein expressions in virus-Infected and uninfected Trichomonas vaginalis. Korean J Parasitol 2017;55(2):121-128.

106. Goodman RP2, Freret TS, Kula T, Geller AM, Talkington MW, Tang-Fernandez V, Suciu O, Demidenko AA, Ghabrial SA, Beach DH, Singh BN, Fichorova RN, Nibert ML. Clinical isolates of Trichomonas vaginalis concurrently infected by strains of up to four Trichomonasvirus species (Family Totiviridae). J Virol 2011;85(9):4258-4270.

107. Bessarab IN, Nakajima R, Liu HW, Tai JH. Identification and characterization of a type III Trichomonas vaginalis virus in the protozoan pathogen Trichomonas vaginalis. Arch Virol 2011;156(2):285-294.

108. Wendel KA, Rompalo AM, Erbelding EJ, Chang TH, Alderete JF. Double-stranded RNA viral infection of Trichomonas vaginalisinfecting patients attending a sexually transmitted diseases clinic. J Infect Dis 2002;186(4): 558-561.
109. Arroyo R, Alderete JF. Two Trichomonas vaginalis surface proteinases bind to host epithelial cells and are related to levels of cytoadherence and cytotoxicity. Arch Med Res 1995;26(3):279-285.

110. Wang AL, Wang CC, Alderete JF. Trichomonas vaginalis phenotypic variation occurs only among trichomonads infected with the double-stranded RNA virus. J Exp Med 1987;166(1):142-150.

111. Wang AL, Wang CC. Viruses of parasitic protozoa. Parasitol.Today 1991;7:76-80.

112. Malik SB, Pightling AW, StefaniakLM, Schurko AM, Logsdon JM. An expanded inventory of conserved meiotic genes provides evidence for sex in Trichomonas vagi $i$ nalis. PLoS One 2008;3:e2879.

113. Khoshnan A, Alderete JF. Characterization of double-stranded RNA satellites associated with the Trichomonas vaginalis virus. J Virol 1995; 69:6892-6897.

114. Heidary S, Bandehpour M, Valadkhani $Z$, Seyyed-Tabaee S, Haghighi A, Abadi A, Kazemi B. Double-stranded RNA viral infection in Tehran Trichomonas vaginalis isolates. Iran J Parasitol 2013;8(1):60-64.

115. Lin WC, Chang WT, Chang TY, Shin JW. The pathogenesis of human cervical epithelium cells induced by interacting with Trichomonas vaginalis. PLoS One 2015 22;10(4):e0124087.

116. Twu O, de Miguel N, Lustig G, Stevens GC, Vashisht AA, Wohlschlegel JA, Johnson PJ. Trichomonas vaginalis exosomes deliver eargo to host cells and mediate hostratioparasite interactions. PLoS pathogens 2013; 9(7):e1003482.

117. Fichorova RN. Impact of T. vaginalis infection on innate immune responses and reproductive outcome. J Reprod Immunol 2009;83:185-189.

118. HAtta-ur-Rahman, Harvey K, Siddiqui RA. Interleukin-8: an autocrine inflammatory mediator. Curr Pharm Des 1999;5:241-253.

119. O'Neil LA, Greene C. Signal transduction pathways activated by the IL-1 receptor family: ancient signnaling machinery in mammals, insects and plants. J Leukoc Biol 1998;63:650-657.

120. Shaio MF1, Lin PR, Liu JY, Tang KD. Monocyte-derived interleukin-8 involved in the 
recruitment of neutrophils induced by Trichomonas vaginalis infection. J Infect Dis 1994;170:1638-1640.

121. Shaio MF2, Lin PR, Liu JY, Yang KD. Generation of interleukin- 8 from human monocytes in response to Trichomonas vaginalis stimulation. Infect Immun 1995;63:3864-3870.

122. Ryu JS, Kang JH, Jung SY, Shin MH, Kim JM, Park H, Min DY. Production of interleukin- 8 by human neutrophils stimulated with Trichomonas vaginalis. Infect Immun. 2004;72:1326-1332.

123. Hitti, Hillier SL, Agnew KJ, Krohn MA, Reisner DP, Eschenback DA. Vaginal indicators of amniotic fluid infection in preterm labor. Obstet Gynecol 2001;97:211-219.

124. Soboll G, Shen L, Wira CR. Expression of Toll like receptors (TLR) and responsiveness to TLR agonists by polarized mouse uterine epithelial cells in culture. Biol Reprod 2006; 75:131-139.

125. Platz-Christensen JJ, IMattsby-Baltzer I, Thomsen P, Wiqvist N. Endotoxin and interleukin-1 alpha in the cervical mucus and vaginal fluid of pregnant women with bacterial vaginosis. Am J Obstet Gynecol 1993;169:1161-1166.

126. Caux C, Vanbervliet B, Massacrier C, AitYahia S, Vaure C, Chemin K, Dieu-Nosjean MC, Vicari A. Regulation of dendritic cell recruitment by chemokines. Transplantation 2002;73(S1):S7-S11.

127. Lekkerkerker AN, van Kooyk Y, Geijtenbeek TB. Viral piracy: HIV-1 targets dendritic cells for transmission. Curr HIV Res 2006;4(2):169-176.

128. Hoebe K, Janssen EM, KimSO, Alexopoulou L, Flavell RA, Han J, Beutler B. Upregulation of co-stimulatory molecules induced by lipopolysaccharide and doublestranded RNA occurs by Trif-dependent and Trif-independent pathways. Nat Immunol 2003;4(12):1223-1229.

129. Burgess, D. Trichomonads and intestinal flagellates, In F. Cox, J. P. Krier, and D. Wakelin (ed.), Topley and Wilson's microbiology and microbial infections, 9th ed. University Press, New York, N.Y. 1998; p. 203-214.

130. Mallinson DJ, Lockwood BC, Coombs GH, North MJ. Identification and molecular cloning of four cysteine proteinase genes from the pathogenic protozoon Trichomo- nas vaǵinalis. Microbiology 1994;140 (Pt 10):2725-2735.

131. Alderete JF, Arroyo R, Lehker MW. Analysis for adhesins and specific eytoadhesion of Trichomonas vaginalis. Methods Enzymol 1995;253:407-414.

132. Addis M 2, Rappelli, Pinto De Andrade AM, Rita FM, M. Colombo MM, Cappuccinelli P, Fiori PL. Identification of Trichomonas vaginalis alpha-actinin as the mostt common immunogen recognized by sera of women exposed to the parasite. J Infect Dis 1999;180(5):1727-1730.

133. Wos SM, Watt RM. Immunoglobulin isotypes of anti-Trichomonas vaginalis antibodies in patients with vaginal trichomoniasis. J Clin Microbiol 1986;24(5):790-795.

134. Krieger JN, Ravdin JI, Rein MF. Contactdependent cytopathogenic mechanisms of Trichomonas vaginalis. Infect Immun 1985;50(3):778-786.

135. Sutton M, Sternberg M, Koumans EH, MeQuillan G, Berman S, Markowitz L. The prevalence of Trichomonas vaginalis infection among reproductive-age women in the United States, 2001-2004. Clin Infect Dis 2007;45(10):1319-1326.

136. Sena AC, Miller WC, Hobbs MM, Schwebke JR, Leone PA, Swygard H, Atashili J, Cohen MS. Trichomonas vaginalis infection in male sexual partners: implications for diagnosis, treatment, and prevention. Clin Infect Dis 2007;44(1):13-22.

137. Wølner-Hanssen P, Krieger JN, Stevens CE, Kiviat NB, Koutsky L, Critchlow C, DeRouen T, Hillier S, Holmes KK. Clinical manifestations of vaginal trichomoniasis. JAMA 1989;261(4):571-576.

138. Lehker MW, Alderete JF. Biology of trichomonosis. Curr Opin Infect Dis 2000;13(1):37-45.

139. Swyg̉ard H, Seña AC, Hobbs MM, Cohen MS. Trichomoniasis: clinical manifestations, diagnosis and management. Sex Transm Infect 2004;80(2):91-95.

140. Lazenby GB, Soper DE, Nolte FS. Correlation of leukorrhea and Trichomonas vaginalis infection. $\mathrm{J}$ Clin Microbiol 2013;51(7):2323-2327.

141. Silver BJ, Guy RJ, Kaldor JM, Jamil MS, Rumbold AR. Trichomonas vaginalis as a cause of perinatal morbidity: a systematic 
review and meta-analysis. Sex Transm Dis 2014;41(6):369-376.

142. Schwandt A, Williams C, Beigi RH. Perinatal transmission of Trichomonas vaginalis: a case report. J Reprod Med 2008; 53(1):59-61.

143. Carter JE, Whithaus KC. Neonatal respiratory tract involvement by Trichomonas vaginalis: a case report and review of the literature. Am J Trop Med Hyg 2008; 78(1):17-19.

144. Mann JR, MeDermott S, Barnes TL, Har$\operatorname{din} \mathbf{J}$, Bao H, Zhou L. Trichomoniasis in pregnancy and mental retardation in children. Ann Epidemiol 2009;19(12):891899.

145. Colotta F, Allavena P, Sica A, Garlanda C, Mantivani A. Cancer-related inflammation, the seventh hallmark of cancer: links to genetic instability. Carcinogenesis 2009;30:1073-1081.

146. Candido J, Hageman T. Cancer-related inflammation. J Clin Immunol,2013;33 (suppl. 1): S79-S84.

147. Costa A, Scholer-Dahirel A, Mecha-Gregoriou $\mathrm{F}$. The role of reactive oxygen species and metabolism on cancer cells and their microenvironment. Semin Cancer Biol 2014;25: 23-32.

148. Parida S, Mandal M. Inflammation induced by human papillomavirus in cervical cancer and its implication in prevention. Eur J Cancer Prev 2014, 23(5):432-448.

149. Castle PE, Hillier SL, Rabe LK, Hildesheim A, Herrero R, Bratti MC, Sherman ME, Burk RD, Rodriguez AC, Alfaro M, Hutchinson ML, Morales J, Schiffman M. An association of cervical inflammation with high-grade cervical neoplasia in women infected with oncogenic human papillomavirus (HPV). Cancer Epidemiol Biomark Prev 2001;10(10):1021-1027.

150. Castle PE, Giuliano AR. Chapter 4: genital tract infections, cervical inflammation, and antioxidant nutrients-assessing their roles as human papillomavirus cofactors. J Natl Cancer Inst Monogr 2003;31:29-34.

151. Khatami M. 'Yin and Yang' in inflammation: duality in innate immune cell function and tumorigenesis. Expert Opin Biol Ther 2008;8:1461-1472.
152. Thompson PA, Khatami M, Bagilole CJ, Sun J, Harris SA, Moon EY, Al-Mulla F, AlTemaimi R, Brown DG, Colacei A, Mondello C, Raju J, Ryan EP, Woodrick J, Scovassi AI, Singh N, Vaceari M, Roy R, Forte S, Memeo L, Salem HK, Amedei A, Hamid RA, Lowe L, Guarnieri T, Bisson WH. Environmental immune disruptors, inflammation and cancer risk. Carcinogenesis 2015;36(Suppl 1):S232-S253.

153. Fichorova RN, Lee Y, Yamamoto HS, Takagi Y, Hayes GR, Goodman RP, Chepa-Lotrea X, Buck OR, Murray R, Kula T, Beach DH, Singh BN, Nibert ML. Endobiont viruses sensed by the human host-beyond conventional antiparasitic therapy. PLoS One 2012;7:e48418.

154. International Agency for Research on Cancer. World Health Organization. Cancer 2018 Reviewed on 2020, June 20. Available from: URL: https://geo.iare.fr/today/ data/factsheets/populations/900-worldfact-sheets.pdf.

155. Pan-American Health Organization. Cáncer Cervicouterino 2018. Reviewed on: 2020, June 20. Available from: URL:https:// www.paho.org/hq/index.php?option $=\mathrm{com}$ content $\&$ view $=$ article $\&$ id $=5420: 2018$-cervical-cancer\&Itemid $=3637 \&$ lang $=e s$.

156. Núñez-Troconis J, Delgado M, González J, Mindiola R, Velásquez J, Conde B, Whitby D, Monroe DJ. Prevalence and risk factors of human papillomavirus infection in asymptomatic women in a Venezuelan urban area. Invest Clin 2009;50(2):203-212.

157. Vielot N, Hudgens MG, Mugo N, Chitwa M, Kimani J, Smith J. The Role of Chlamydia trachomatis in high-risk human papillomavirus persistence among female sex workers in Nairobi, Kenya. Sex Transm Dis 2015;42(6):305-311.

158. Ye H, Song T, Zeng X, Li L, Hou M, Xi M. Association between genital mycoplasmas infection and human papillomavirus infection, abnormal cervical cytopathology, and cervical cancer: a systematic review and meta-analysis. Arch Gynecol Obstet 2018;297(6):1377-1387.

159. Ghosh I, Mandal R, Kundu P, Biswas J. Association of genital infections other than human papillomavirus with pre-Invasive and 
invasive cervical neoplasia. J Clin Diaǵn Res 2016;10(2):XE01-XE06.

160. IARC Working Group on the Evaluation of Carcinogenic Risk to Humans. Biological Agents. Lyon (FR): International Agency for Research on Cancer; 2012. (IARC Monographs on the Evaluation of Carcinogenic Risks to Humans, No. 100B.) Available from: https://www.ncbi.nlm.nih.gov/ books/ NBK304348/. Reviewed on July 22, 2020 .

161. Schiffman MH, Castle P. Epidemiologic studies of a necessary causal risk factor: human papillomavirus infection and cervi- cal neoplasia. J Natl Cancer Inst 2003, 95:E2.

162. Scheurer ME, Tortolero-Luna G, AdlerStorthz K. Human papillomavirus infection: biology, epidemiology, and prevention. Int J Gynecol Cancer 2005, 15:727-746.

163. Verteramo R1, Pierangeli A, Mancini E, Calzolari E, Bucei M, Osborn J, Nicosia R., Chiarini F, Antonelli G, Degener AM. Human papillomaviruses and genital coinfections in gynaecological outpatients. BMC Infect Dis 2009;9:16.

164. Múñoz N, Castellsague $X$, de Gonzalez AB, Gissmann L. HPV in the etiology of human cancer. Vaccine 2006; 24(S3):S1-S10.

165. Flores R, Papenfuss M, Klimecki WT, Giuliano AR. Cross-sectional analysis of oncogenic HPV viral load and cervical intraepithelial neoplasia. Int J Cancer 2006; 118(5):1187-1193.

166. Riva E, Serraino D, Pierangeli A, Bambacioni F, Zaniratti S, Minosse C, Selleri M, Bucei M, Seagnolari C, Degener AM, Capobianchi MR, Antonelli G, Dianzani F, the Roman Papillomavirus Study Group. Markers of human papillomavirus infection and their correlation with cervical dysplasia in human immunodeficiency virus-positive women. Clin Microbiol Infect 2007;13(1):94-97.

167. Clifford GM, Goncalves MA, Franceschi S, HPV and HIV Study Group. Human papillomavirus types among women infected with HIV: a meta-analysis. AIDS 2006; 20(18):2337-2344.

168. Vaccarella S, Herrero R, Dai M, Snijders PJ, Meijer CJ, Thomas JO, Hoang Anh PT, Ferreceio C, Matos E, Posso H, de Sanjosé S, Shin HR, Sukvirach S, Lazeano-Ponce
E, Ronco G, Rajkumar R, Qiao YL, Muñoz N, Franceschi S. Reproductive factors, oral contraceptive use, and human papillomavirus infection: pooled analysis of the IARC HPV prevalence surveys. Cancer Epidemiol Biomarkers Prev 2006;15(11):2148-2153.

169. Vacearella S, Franceschi S, Herrero $R$, Muñoz N, Snijders PJ, Clifford M, Smith JS, Lazcano-Ponce E, Sukvirach S, Shin HR, de Sanjosé S, Molano M, Matos E, Ferreceio C, Anh PT, Thomas JO, Meijer CJ, IARC HPV Prevalence Surveys Study Group. Sexual behavior, condom use, and human papillomavirus: pooled analysis of the IARC human papillomavirus prevalence surveys. Cancer Epidemiol Biomarkers Prev 2006;15(2):326-333.

170. Verteramo R, Pierangeli A, Calzolari E, Patella A, Recine N, Mancini E, Marcone V, Masciangelo R, Bucci M, Antonelli G, Degener AM. Direct sequencing of HPV DNA detected in gynaecologic outpatients in Rome, Italy. Microbes Infect 2006; 8(10):2517-2521.

171. Lv P, Zhao F, Xu X, Xu J, Wang Q, Zhao Z. Correlation between common lower genital Ttract microbes and high-risk Human Papillomavirus infection. Can J Infect Dis Med Microbiol 2019;2019:9678104.

172. Noël JC, Fayt I, Romero Munoz MR, Simon P, Engohan-Aloghe C. High prevalence of high-risk human papillomavirus infection among women with Trichomonas vaginalis infection on monolayer cytology. Arch Gynecol Obstet 2010; 282(5):503-505.

173. Thurman AR, Doncel GF. Innate immunity and inflammatory response to Trichomonas vaǵinalis and bacterial vaǵinosis: relationship to HIV aequisition. Am J Reprod Immunol 2011;65:89-98.

174. Hirt RP. Trichomonas vaginalis virulence factors: an integrative overview. Sex Transm Infect 2013;89:439-443.

175. Gram IT, Macaluso M, Churchill J, Stalsberg H. Trichomonas vaǵinalis (TV) and human papillomavirus (HPV) infection and the incidence of cervical intraepithelial neoplasia (CIN) grade III. Cancer Causes Control 1992;3(3):231-236.

176. Donders GG, Depuydt CE, Bogers JP, Vereecken AJ. Association of Trichomonas vaginalis and cytological abnormalities of 
the cervix in low risk women. PLoS One 2013;8(12):e86266.

177. Tao L, Han L, Li X, Gao Q, Pan L, Wu L, Luo Y, Wang W, Zheng Z, Guo X. Prevalence and risk factors for cervical neoplasia: a cervical cancer screening proǵram in Beijing. BMC Public Health.2014;14:1185.

178. Depuydt CE, Leuridan E, Van Damme P, Bogers J, Vereecken AJ, Donders GG. Epidemiology of Trichomonas vaginalis and human papillomavirus infection detected by real-time PCR in Flanders. Gynecol Obstet Invest 2010; 70(4):273-280.
179. Feng RM, $Z$ Wang $M$, Smith JS, Dong L, Chen F, Pan QJ, Zhang x, Ciao YL, Zhao FH. Risk of high-risk human papillomavirus infection and cervical precancerous lesions with past or current trichomonas infection: a pooled analysis of 25,054 women in rural China. J Clin Virol 2018;99. 100:84-90.

180. Yap EH, Ho TH, Chan YC, Thong TW, Ng GC, Singh M. Serum antibodies to Trichomonas vagínalis in invasive cervical cancer patients. Genitourin Med 1995;71(6):402404. 